\title{
Effect of wastewater sludge application on enzyme activities in soil contaminated with crude oil
}

\author{
Efsun Dindar*, Fatma O. Topac, Hüseyin S. Baskaya, Tuba Kaya
}

Uludag University, Faculty of Engineering, Department of Environmental Engineering, 16059 Görükle, Bursa, Turkey.*Corresponding author: efsun@uludag.edu.tr

\begin{abstract}
Crude oil affects soil ecosystems, resulting in significant losses in soil quality. The objective of the present study was to evaluate the effects of hydrocarbon pollution (crude oil) on soil enzyme activities and determine the removal of total petroleum hydrocarbons (TPH) during an incubation period of 150 days. The potential use of wastewater sludge as a biostimulating agent in petroleum-contaminated soils was also evaluated. The degradation of crude oil in contaminated soil was significantly enhanced after the addition of wastewater sludge. The results also indicated that significant TPH degradation in crude oil-contaminated soils $(80 \%$ for dose of $0.5 \%$ and $83 \%$ for dose of $5 \%$ at $\left.18{ }^{\circ} \mathrm{C}\right)\left(94 \%\right.$ for dose of $0.5 \%$ and $92 \%$ for dose of $5 \%$ at $\left.28{ }^{\circ} \mathrm{C}\right)$ occurred after an incubation period of 150 days. Enhanced enzyme activity levels in contaminated soils indicated that crude oil $(0.5 \%$ and $5 \%, \mathrm{w} / \mathrm{w})$ stimulated microbial growth and enzyme activity in the soil environment. Urease activity (UA) levels in crude oil contaminated soils were generally higher than initial UA levels in soil during the incubation period. Soil UA exhibited a stronger response to petroleum treatment. Alkaline phosphatase (APA) and $\beta$-Glucosidase (BGA) activities were not affected crude oil pollution. However, contamination of crude oil had a negatively effect on soil dehydrogenase activity (DHA).
\end{abstract}

Keywords: Biostimulation, enzyme activities, incubation, TPH, soil 


\section{Introduction}

Crude oil pollution is the most prevalent problem in the environment. The release of crude oil into the environment after oil spills has received much attention worldwide. Crude oil occurs naturally as a complex mixture of hydrocarbon and non-hydrocarbon compounds, containing measurable toxicity towards living organisms (Marinescu et al., 2011). The incidence of oil spillage in different parts of the world leads to serious problems and increases hazards to the environment. Crude oil pollution also leads to the deterioration of soil structure, loss of organic matter contents, loss of soil mineral nutrients, and also exposes soil to leaching and erosion (Palese et al., 2003). The activities of soil enzymes such as dehydrogenases, oxidases, lipases, ureases and alkaline phosphatase are reduced or inhibited. The use of organic amendments to improve soil quality and fertility dates back to thousands of years ago. Nowadays the most common soil organic amendments are compost, animal manure or wastewater sludge are used. Wastewater sludge contains organic matter and nutrients. Crude oil spillage is one of the factors that affect biological activities in the soil. A range of physicochemical and environmental parameters and perturbations influence soil biological activity, including soil microbial biomass and enzymatic activity. Therefore, soil microbial activity is commonly used to assess disturbed soil (Alrumman et al., 2015).

Enzyme activities have been demonstrated as indicators of biogeochemical cycles, the degradation of organic matter and soil remediation processes; thus, these enzymes can determine, together with other physical or chemical properties, the quality of the soil (Gianfreda 2015). Dehydrogenase oxidises soil organic matter through the transfer of protons and electrons from substrates to acceptors. These processes are part of the respiration pathways of soil microorganisms and are closely associated with the type of soil and soil air-water conditions. Because these processes are part of the respiration pathways of soil microorganisms, studies on the activities of soil dehydrogenase are important, as the results might provide information concerning the potential of the soil to support biochemical processes that are essential for maintaining soil fertility (Makoi and Ndakidemi 2008).

Phosphatase is an enzyme of great agronomic value because it hydrolyses and transforms organic phosphorus compounds into different forms of inorganic phosphorus, which can subsequently be assimilated by plants (Pascual et al., 2002). In soil ecosystems, phosphatase play critical roles in $\mathrm{P}$ cycles, as these enzymes have been associated with P stress and plant growth. $\beta$-Glucosidase is characteristically useful as a soil quality indicator and might reflect past biological activity and the capacity of soil to stabilise soil organic matter. $\beta$-Glucosidase can also be used to detect management effects on soils, which has greatly facilitated the adoption of this enzyme for soil quality testing (Bandick and Dick 1999). Generally, $\beta$-glucosidase activities provide advanced evidence of changes in organic carbon long before it can be accurately measured using other routine methods.

Urease is involved in urea hydrolysis into $\mathrm{CO}_{2}$ and $\mathrm{NH}_{3}$ and, consequently, with soil $\mathrm{pH}$ increase and $\mathrm{N}$ losses through $\mathrm{NH}_{3}$ volatilisation. Urease has been widely used to evaluate changes in soil quality associated with management, as the activity of this enzyme increases with organic fertilisation and decreases with soil tillage. Urease is primarily an extracellular enzyme, representing up to $63 \%$ of the total activity in soil (Martinez-Salgado et al., 2010).

The use of indigenous microorganisms in bioremediation processes can reduce the risks associated with hydrocarbon-contaminated soils. Several soil enzyme 
activities have been proposed to evaluate and monitor the remediation of hydrocarboncontaminated soil. In the present study, the enzyme activities of dehydrogenase, alkaline phosphatase, $\beta$-glucosidase and urease were used as indicators to assess the recovery of hydrocarbon-impacted soils.

The objective of the present study was to examine the levels of total petroleum hydrocarbons (TPH) and the effects of hydrocarbon pollution (crude oil) on soil enzyme activities during 150 days.

\section{Materials and Methods}

\subsection{Materials}

Soil samples were collected from the top 20 $\mathrm{cm}$ of an agricultural field located in BursaBalabanc1k Village (latitude, $40^{\circ} 15^{\prime}$, 55.1", $\mathrm{N}$; longitude, $\left.28^{\circ} 47^{\prime} 07.55^{\prime \prime} \mathrm{E}\right)$. The soil chemical properties are shown in Table 1. The canned food wastewater sludge samples were obtained from a food company treatment plant in Bursa, Turkey. The general characteristics of the canned food sludge are presented in Table 1. Light crude oil was collected from a refinery in Izmir, Aliağa, showing a specific gravity of $0.86(60 \mathrm{~F} / 60 \mathrm{~F})$, gravity of $33.4 \mathrm{API}$, viscosity of $10.20 \mathrm{cs}(70 \mathrm{~F})$, total sulphur of $1.79 \%$ (wt), vanadium of $20.50 \mathrm{ppm}$, nickel of $4.40 \mathrm{ppm}$, and total nitrogen of $0.0980 \%(w t)$.

\subsection{Determination of soil and wastewater} sludge physical and chemical properties

Soil and wastewater sludge samples were prepared and analysed using the same procedures. The EC and $\mathrm{pH}$ of the samples were
Table 1. The chemical properties of soil and wastewater sludge from canned food industry.

\begin{tabular}{|c|c|c|}
\hline \multirow[t]{2}{*}{ Properties } & \multicolumn{2}{|l|}{ Value } \\
\hline & Sludge & Soil \\
\hline $\mathrm{pH}$ ( $1: 5$ deionised water $)$ & 6.97 & 7.76 \\
\hline $\mathrm{EC}_{25^{\circ} \mathrm{C}}\left(1: 5\right.$ deionised water, $\left.\mathrm{dS} \mathrm{m}^{-1}\right)$ & 5.04 & 0.16 \\
\hline Organic C, $\%$ & 33.50 & 1.23 \\
\hline Total-P, $\%$ & 0.50 & 0.17 \\
\hline Total-N, \% & 3.50 & 0.15 \\
\hline $\mathrm{NH}_{4}-\mathrm{N}, \mathrm{mg} / \mathrm{kg}$ dry weight & 201.93 & 24.1 \\
\hline $\mathrm{NO}_{3}-\mathrm{N}, \mathrm{mg} / \mathrm{kg}$ dry weight & 171.64 & 24.1 \\
\hline Alkaline phosphatase Activity (mg PNP kg ${ }^{-1} \cdot h^{-1}$ ) & 1266 & 246 \\
\hline B-glucosidase Activity $\left(\mathrm{mg} \mathrm{PNP} \mathrm{kg}^{-1} \cdot \mathrm{h}^{-1}\right)$ & 820 & 146 \\
\hline Urease Activity $\left(\mathrm{mg} \mathrm{NH}_{4}-\mathrm{N} \mathrm{kg}^{-1} \cdot \mathrm{h}^{-1}\right)$ & 34 & 26 \\
\hline Dehydrogenase Activity (mg TPF kg ${ }^{-1} \cdot \mathrm{h}^{-1}$ ) & 6 & 5 \\
\hline $\mathrm{Zn}\left(\mathrm{mg} \mathrm{kg}^{-1}\right.$ dry weight) & 122.8 & 1.35 \\
\hline \multicolumn{3}{|l|}{ Exchangeable heavy metals ( $\mathrm{mg} \mathrm{kg}^{-1}$ dry weight $)$} \\
\hline $\mathrm{Cu}$ & 27.55 & 2.05 \\
\hline $\mathrm{Ni}$ & 11.20 & $<1.00$ \\
\hline $\mathrm{Cr}$ & 0.11 & $<1.00$ \\
\hline $\mathrm{Cd}$ & 0.09 & $<2$ \\
\hline $\mathrm{Pb}$ & 1.79 & $<2$ \\
\hline \multicolumn{3}{|l|}{ Total heavy metals (mg/ kg dry weight): } \\
\hline $\mathrm{Zn}$ & 334.2 & 65.02 \\
\hline $\mathrm{Cu}$ & 53.50 & 15.34 \\
\hline $\mathrm{Ni}$ & 58.29 & 128.0 \\
\hline $\mathrm{Cr}$ & 48.20 & 98.69 \\
\hline $\mathrm{Cd}$ & 3.50 & 0.21 \\
\hline $\mathrm{Pb}$ & 11.66 & trace \\
\hline
\end{tabular}

measured using a conductivity meter and $\mathrm{pH}$ meter, respectively, and the extracts were analysed after shaking the soil or wastewater sludge samples with distilled water $(1: 5, \mathrm{w} / \mathrm{v})$ (Rhoades 1982; McLean 1982).

The Kjeldahl digestion method was used to measure the total nitrogen concentration (Bremner and Mulvaney 1982). In addition, dichromate oxidation was used to measure the total organic carbon (Nelson and Sommer 1982). Total phosphorus (P) was colourimetrically measured using a UV/VIS spectrophotometer (Anonymous 1985). The total concentrations of metals $(\mathrm{Cr}, \mathrm{Ni}, \mathrm{Cu}$ and $\mathrm{Zn}$ ) were determined after microwave digestion of the samples with $\mathrm{HNO}_{3}$ using an ICP OES (Perkin Elmer 2100 DV Optima) (Isaac and Johnson 1998).

\subsection{Determination of soil enzyme activities}

The alkaline phosphatase (APA), $\beta$-glucosidase (BGA), dehydrogenase (DHA) and urease (UA) enzymatic activities were determined according to the methods of Tabatabai (1994). 
The alkaline phosphatase activities were determined after adding a modified universal buffer $(\mathrm{pH}=11)$, $0.025 \mathrm{M}$ toluene and p-nitrophenyl phosphate solutions to the soil. $\beta$-Glucosidase activities were measured after adding a modified universal buffer $(\mathrm{pH}=6), 0.025 \mathrm{M}$ toluene and p-nitrophenyl- $\beta$ - $\mathrm{D}$ glucoside (PNG) solutions to the soil. Samples from both analyses were subsequently incubated at 37 ${ }^{\circ} \mathrm{C}$ for $1 \mathrm{~h}$. The released p-nitrophenol (PNP) was quantified using a spectrophotometer at $410 \mathrm{~nm}$. The $\beta$-glucosidase activity test was based on the colourimetric determination of PNP. Similarly, the assay for urease activity was based on the determination of $\mathrm{NH}_{4}^{+}$released from urease when the soil was incubated with THAM (Tris (hydroxymethyl) aminomethane) buffer $(\mathrm{pH}=9)$, a $0.02 \mathrm{M}$ urea solution and toluene at $37{ }^{\circ} \mathrm{C}$ for $2 \mathrm{~h}$. The formation of ammonium was determined using steam distillation. The steam distillation was performed with $\mathrm{MgO}$ and Devarda alloy (automatic distillation system-Velp) to analyse the nitrate and ammonium nitrogen concentrations in samples extracted with $2 \mathrm{M} \mathrm{KCl}$ (Keeney and Nelson 1982).

The dehydrogenase activities were determined by adding a triphenyl tetrazolium chloride solution (3\%) to soil samples prior to incubating the suspensions at $37{ }^{\circ} \mathrm{C}$ for 24 hours. The formation of TPF (triphenyl formazan) was determined with a spectrophotometer at $485 \mathrm{~nm}$.

\subsection{Determination of total petroleum hydrocarbons in soil}

The TPH concentration was determined using ISO 16703:2004. Petroleum-contaminated soil, $20 \mathrm{~g}$, was weighed and put into a glass extraction vessel with $40 \mathrm{ml}$ of acetone. After briefly shaking by hand, 20 $\mathrm{ml}$ of the RTW (Retention Time Window)-standard solution was added. The specimens were extracted for 60 min using mechanical shaking. After the solid material settled, the supernatant was transferred into a separatory funnel. The acetone was removed after washing the organic phase twice by thorough shaking (5 min) with $100 \mathrm{ml}$ of water. The organic layer was collected in a glass tube. Subsequently, sodium sulphate was added, and $10 \mathrm{ml}$ of extract was transferred to a clean-up column filled with Florisil. An aliquot of the purified extract was placed in a GCvial and analysed using GC-FID. The extracts were analysed in random order within a single batch using gas chromatography with an HP Agilent 7890A gas chromatograph (Agilent Technologies, www.agilent. com) equipped with a FID detector, an Agilent 7693 autosampler and a low-bleed HP-5MS (Agilent part no: 19091S-433) capillary column (30 m x $0.25 \mathrm{~mm}$ i.d.) with a nominal film thickness of $0.25 \mathrm{~mm}$. Splitless injection method was used with a deactivated, splitless inlet liner with adsorbent material and taper (Agilent Technologies, P/N 5183-4711). The injection temperature was $350{ }^{\circ} \mathrm{C}$, and the injection volume was $2 \mu 1$. Helium ( $2 \mathrm{ml} \mathrm{min}^{-1}$ ) was used as the carrier gas. The final GC oven program started at $35^{\circ} \mathrm{C}$, was held for $1.5 \mathrm{~min}$, subsequently increased to $60{ }^{\circ} \mathrm{C}$ at $5{ }^{\circ} \mathrm{C} \mathrm{min}^{-1}$, followed by an increase to 350 ${ }^{\circ} \mathrm{C}$ at $15{ }^{\circ} \mathrm{C} \mathrm{min}{ }^{-1}$ and a final hold at $350{ }^{\circ} \mathrm{C}$ for 10 min. According to the standard methodology (ISO 16703:2004), the amount of total petroleum hydrocarbons (TPH) was subsequently determined as the sum parameter of resolved and unresolved components eluted from the GC capillary column between the retention times of "n-decane" and "n-tetracontane".

\subsection{Incubation procedure}

The soil samples were air-dried in the laboratory and sieved through $2 \mathrm{~mm}$ screens. Subsequently, $40 \mathrm{~g}$ of soil was placed in cylindrical glass pots and contaminated with $0.5 \%$ and $5 \%(\mathrm{w} / \mathrm{w})$ crude oil, followed 
by thorough mixing. Soil with no crude oil addition served as a control. After the oil addition, the wastewater sludge was thoroughly mixed with the soils at ratios equivalent to $40 \mathrm{~g} \mathrm{~kg}^{-1}$ based on dry weight. The pots were incubated for 150 days in the dark at 18 and $28 \pm 0.5^{\circ} \mathrm{C}$. The moisture content in soil was maintained at $70 \%$ field capacity throughout the incubation period.

The sacrificial soil samples were analysed once a month during the incubation period.

\subsection{Statistical analysis}

All statistical calculations were performed using STATISTICA 12.0 software (StatSoft Software 2013). Two-way analysis of variance of ANOVA was conducted to test the effect of sludge amendment and incubation time (Tables 2). The effect of temperature on enzyme activities was further tested using one-way ANOVA for each contaminant dose. When significant effects were indicated, post hoc analysis was performed using Tukey's HSD multiple comparison test.

Table 2. Summarized results of ANOVA with repeated measures for enzymatic activities of crude oil contaminated soil amended with wastewater sludge.

\begin{tabular}{|c|c|c|c|c|}
\hline Sources of Variation & df & MS & $\mathrm{F}$ & $p$ \\
\hline \multicolumn{5}{|c|}{ Dependent Variable: Alkaline phosphatase Activity } \\
\hline Sludge amendment & 2 & 496426 & 53.98 & $<0.001$ \\
\hline Time & 2 & 690076 & 75.04 & $<0.001$ \\
\hline Sludge amendment $\mathrm{x}$ time & 4 & 825549 & 89.77 & $<0.001$ \\
\hline Error & 18 & 9195 & & \\
\hline \multicolumn{5}{|c|}{ Dependent Variable: $\beta$-glucosidase Activity } \\
\hline Sludge amendment & 2 & 150868 & 13.84 & $<0.001$ \\
\hline Time & 2 & 365662 & 33.56 & $<0.001$ \\
\hline Sludge amendment $\mathrm{x}$ time & 4 & 164541 & 15.10 & $<0.001$ \\
\hline Error & 18 & 10893 & & \\
\hline \multicolumn{5}{|c|}{ Dependent Variable: Urease Activity } \\
\hline Sludge amendment & 2 & 11607 & 71.90 & $<0.001$ \\
\hline Time & 2 & 2013 & 12.47 & $<0.001$ \\
\hline Sludge amendment $\mathrm{x}$ time & 4 & 2162 & 13.39 & $<0.001$ \\
\hline Error & 18 & 161 & & \\
\hline \multicolumn{5}{|c|}{ Dependent Variable: Dehydrogenase Activity } \\
\hline Sludge amendment & 2 & 114542 & 48.33 & $<0.001$ \\
\hline Time & 2 & 92547 & 16.85 & $<0.001$ \\
\hline Sludge amendment $\mathrm{x}$ time & 4 & 45638 & 18.24 & $<0.001$ \\
\hline Error & 18 & 8752 & & \\
\hline
\end{tabular}

\section{Results}

The results for the physical and chemical properties of the soil and the wastewater sludge are presented in Table 1. Chemical properties varied among the sludge. The sludge was slightly acidic, with $\mathrm{pH}$ value 6.97. The EC of the wastewater sludge was $5040 \mathrm{dS} / \mathrm{m}^{-1}$. In addition, the results showed that the sludge was an important potential source of plant nu- trients. The total $\mathrm{N}$ and $\mathrm{P}$ contents of the wastewater sludge was $3.5 \%$ and $0.15 \%$, respectively.

The sludge contained relatively low extractable quantities of mineral $\mathrm{N}$ compared with the total $\mathrm{N}$ content (201.93 and $171.64 \mathrm{mg} \mathrm{kg}^{-1}$ ammonium-N and nitrate- $\mathrm{N}$, respectively). The organic carbon content of the wastewater sludge was $33.50 \%$ and could provide organic matter to soil if high rates are applied. 
Total concentrations of $\mathrm{Cd}, \mathrm{Cr}, \mathrm{Ni}, \mathrm{Pb}, \mathrm{Cu}$ and $\mathrm{Zn}$ in the sludge samples are also shown in Table 1. With regards to the concentration of heavy metal levels in sludge were lower than the permissible levels for agricultural use. The soil used in the experiment had a clay loam texture and the $\mathrm{pH}$ indicated that the soil was slightly alkaline, which is common for soils in Turkey. The soil had moderate lime and organic matter contents and a low salt content. According to Table 2 , statistical results indicated that sludge and incubation time significantly affected the enzyme activities. It has been determined that there is an interaction between sludge application and time.

\subsection{Variations in total petroleum hydrocarbons in crude oil-contaminated soils}

The variation of total petroleum hydrocarbon (TPH) levels in oil-contaminated and oil-contaminated + sludge-amended soils during the incubation period of 150 days is illustrated in Figure 1 and Figure 2. The application of $0.5 \%$ and $5 \%$ crude oil resulted in an initial TPH concentration of 4735 and $42860 \mathrm{mg} \mathrm{kg}^{-1}$ in contaminated soils, respectively. The results showed that the addition of wastewater sludge positively affected the removal of TPH from soil contaminated with crude oil. During the incubation period, the TPH levels in crude oil-contaminated soil significantly decreased.

As shown in Figure 1 and Figure 2, much of the TPH removal was realised during the 30-60 days of incubation. For $18^{\circ} \mathrm{C}$ and $28^{\circ} \mathrm{C}$, approximately $60 \%$ and $86 \%$ of TPH, respectively, was removed at the end of 60 days, and thereafter, only slight removal was observed. The TPH removal percentage in crude oil-contaminated $(0.5 \%$ and $5 \%)$ soil was calculated as $80 \%$ and $83 \%$, respectively, at the end of the incubation period for $18{ }^{\circ} \mathrm{C}$. As shown in Figure 1a and 1b, the TPH levels in crude oil-contaminated and sludge-amended soils were lower than those in contaminated soil. As indicated in Figure 1a, variations in the TPH levels in crude oil-polluted $(0.5 \%$ and $5 \%)$ and sludge-amended soils during the incubation period indicated that $80 \%$ removal of TPH was achieved within a 150 days period.
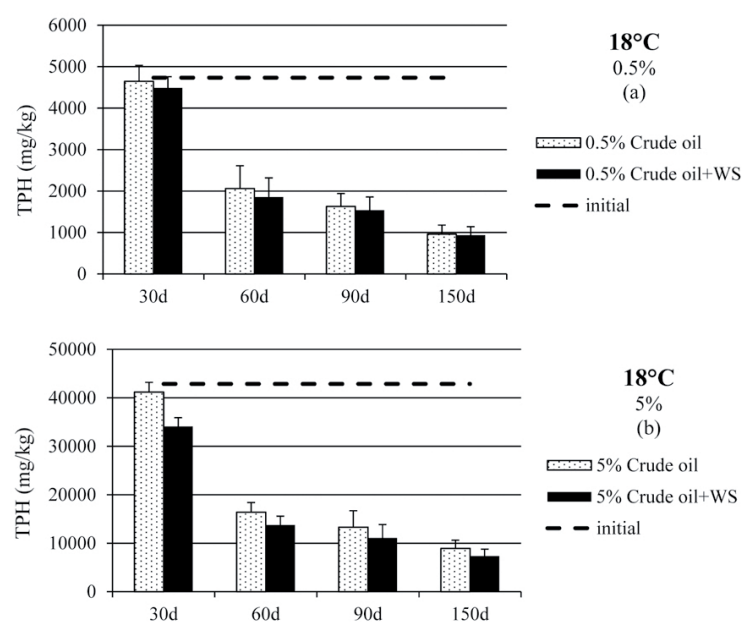

Figure 1. Changes in TPH levels in soil contaminated with crude oil $(0.5 \%$ and $5 \%)$ and canned food industry sludgeamended soil during the incubation period at $18{ }^{\circ} \mathrm{C}$.

(WS: wastewater sludge)

Figure 2 shows variations in the TPH levels in soils contaminated with crude oil $(0.5 \%$ and $5 \%, \mathrm{w} / \mathrm{w})$ after an incubation period of 150 days. At the end of the incubation period, the TPH levels in crude oil-contaminated soil significantly decreased at $28^{\circ} \mathrm{C}$. 

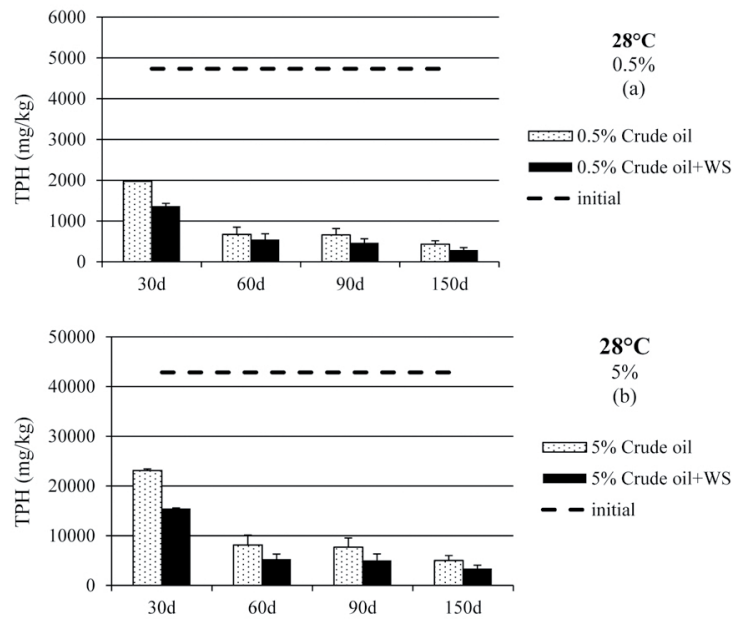

Figure 2. Changes in TPH levels in soil contaminated with crude oil $(0.5 \%$ and $5 \%)$ and canned food industry sludgeamended soil during the incubation period at $28^{\circ} \mathrm{C}$.

(WS: wastewater sludge)

The results showed that high temperatures $\left(28^{\circ} \mathrm{C}\right)$ significantly contributed to the removal of TPH in soil contaminated with crude oil. As shown in Figure 2, the addition of wastewater sludge positively affected the removal of TPH in soil contaminated with crude oil.

The results showed that the TPH levels in crude oilcontaminated and sludge-amended soils were apparently lower than those in contaminated soil. After incubation at $28{ }^{\circ} \mathrm{C}$ for 150 days, the removal rate for soil samples contaminated with crude oil $(0.5 \%)$ was $91 \%$, whereas treatment with wastewater sludge increased this ratio to $94 \%$. For soil contaminated with crude oil $(5 \%)$ at $28{ }^{\circ} \mathrm{C}$, the TPH biodegradation rate was $87 \%$, which increased to $92 \%$ after treatment with wastewater sludge. The highest biodegradation rate was observed for soil contaminated with crude oil and treated with wastewater sludge at $28^{\circ} \mathrm{C}$.

\subsection{Variations of soil enzyme activities in crude oil-contaminated soils}

Variations in urease activity (UA) levels in oilcontaminated and oil-contaminated+sludgeamended soils during the 150-days incubation period are illustrated in Figure 3.

In the case of crude oil contamination $(0.5 \%)$, UA levels were significantly lower than the levels of oil-contaminated+sludge-amended soils after all incubation periods. For the high dose of contamination (5\%), the results of the incubation study indicated that wastewater sludge amendment further increased the UA levels in contaminated soils for the last 60 days of incubation. This delayed increment in urease activity likely reflected the delayed mineralisation of wastewater sludge. UA levels in soil contaminated with a high dose of crude oil $(5 \%)$ and treated with wastewater sludge were higher than those in other applications for the last three months of the incubation period. The enzyme activity levels were generally higher at high temperatures $\left(28{ }^{\circ} \mathrm{C}\right)$. The application of crude oil $(0.5 \%$ and $5 \%)$ resulted in an initial UA concentration of $60 \mathrm{mg} \mathrm{kg}^{-1}$ in contaminated soils, showing that the UA levels in crude oil contaminated soils were generally higher than initial UA levels in soil during the incubation period. As the incubation time increased, the UA levels in soil contaminated with crude oil decreased at both contamination doses. The delayed stimulating effect of crude oil on soil UA was observed after incubation at $28{ }^{\circ} \mathrm{C}$ for 30 days. The observed increment in UA levels 

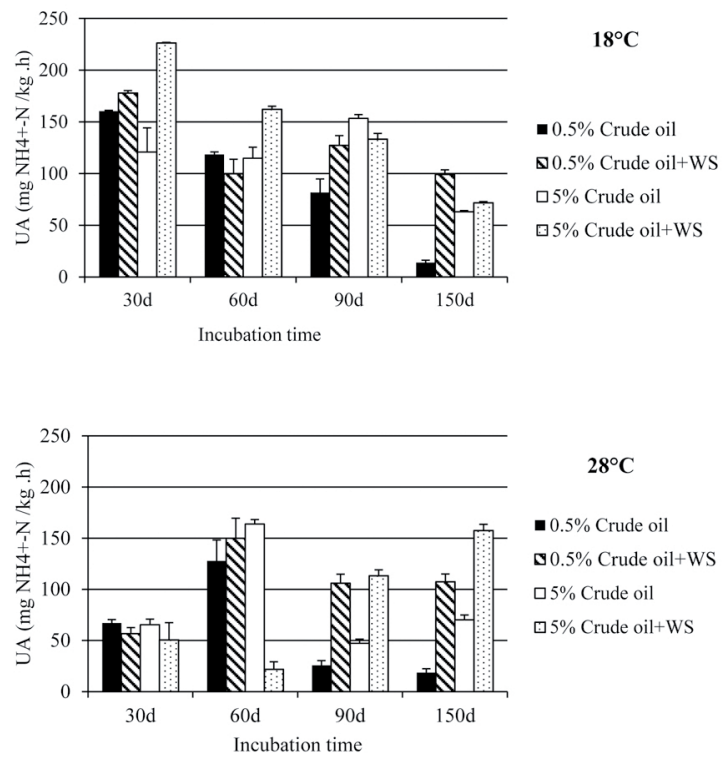

Figure 3. Changes in urease activity in contaminated and sludge-amended soil during the incubation period (WS: wastewater sludge)
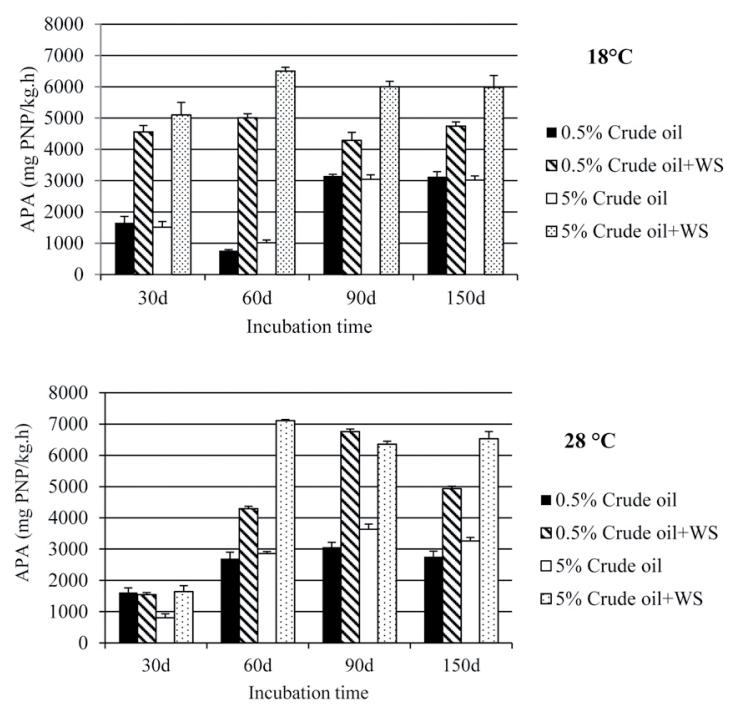

Figure 4. Changes in APA in contaminated and sludgeamended soil during the incubation period (WS: wastewater sludge) might have important implications in terms of the ability of microorganisms to use ammonium as a nitrogen source for biodegradation under the experimental conditions. Figure 4 shows the variations of APA in crude oil-contaminated and crude oil-contaminated + sludgeamended soils.

The application of wastewater sludge to soils contaminated with crude oil apparently increased APA levels at both levels of pollution. After incubation at $28{ }^{\circ} \mathrm{C}$, the APA levels were generally similar in soils contaminated with high and low doses of crude oil. The highest level of APA was observed in sludge-amended soils with high levels of crude oil pollution (5\%). However, the APA levels increased in all amendments throughout the entire incubation period, and the most pronounced increments were observed after the first two months of incubation.

As indicated in Figure 4, after incubation at $18{ }^{\circ} \mathrm{C}$, no significant difference with respect to APA levels was determined between soils contaminated with high and low doses of crude oil. However, wastewater sludge amendments were more efficient for soils contaminated with 5\% crude oil. While an apparent increasing activity trend was observed in all heavily contaminated soils, the APA levels in soils contaminated with a low dose of crude oil did not significantly vary throughout the incubation period. The results indicated that the highest APA level was determined in contaminated ( $5 \%$ crude oil) and wastewater sludge-amended soil pots after incubation for 60 days.

The application of crude oil $(0.5 \%$ and $5 \%)$ resulted in an initial APA concentration of $1512 \mathrm{mg} \mathrm{kg}^{-1}$ in contaminated soils. The results showed that the APA levels in crude oilcontaminated soils were apparently higher than 
the initial levels in soil during the incubation period. At $18{ }^{\circ} \mathrm{C}$, the addition of crude oil inhibited soil APA only at the end of the 60-day incubation period.

Variations in the $\beta$-glucosidase activity levels in crude oil-contaminated and crude oil-contaminated + sludge amended soils during the 150-day incubation period are shown in Figure 5. The results showed that the $\beta$-glucosidase activity levels in crude oil-contaminated soils $(0.5 \%)$ were apparently higher than those in sludge-amended soil at $28^{\circ} \mathrm{C}$ for 90 days. The level of BGA in soils contaminated with crude oil was negatively affected after the addition of wastewater sludge. After the application of 5\% crude oil, wastewater sludge amendment showed no significant variations during incubation period. The BGA levels in soils contaminated with crude oil decreased with increasing incubation time. The enhancement effect of wastewater sludge application on soil with crude oil was observed after the 90-day incubation period.

The application of crude oil $(0.5 \%$ and $5 \%)$ +sludge amended resulted in an initial BGA concentration of $966 \mathrm{mg} \mathrm{kg}^{-1}$ in contaminated soils. The results showed that the BGA levels in crude oil-contaminated soils were apparently lower than those in control soil at the end of the incubation period. This decrease indicated that the contamination of crude oil had detrimental effects on BGA for both contaminant doses. Wastewater sludge amendment slightly increased the BGA of both oil-contaminant doses. The increased BGA levels in oil-contaminated soil might also reflect the enhanced microbial activity under the experimental conditions.

At $18{ }^{\circ} \mathrm{C}$, the results of the incubation study indicated that wastewater sludge amendment further increased the BGA levels of $0.5 \%$ oil- contaminated soils at the initial stage (30-60 days) of incubation. Following the first 60-day period, the BGA levels in oil-contaminated+sludge-amended soil samples were significantly lower than those in oil-contaminated soil $(p<0.05)$.
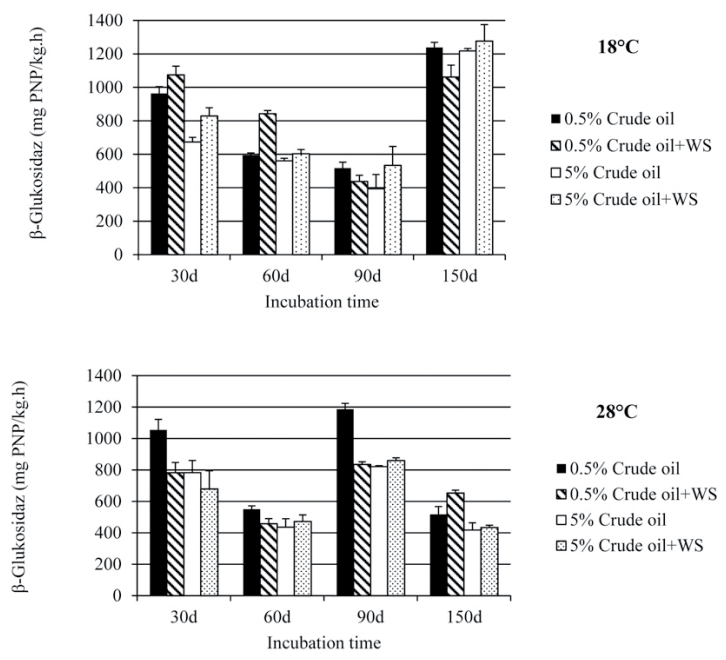

Figure 5. Changes in BGA in contaminated and sludgeamended soil during the incubation period (WS: wastewater sludge)

However, the BGA levels in crude oil-contaminated soils $(0.5 \%$ and $5 \%)$ were similar to or lower than the control levels during the first 90 days of incubation. As the incubation time increased, the BGA levels in soil contaminated with crude oil increased.

The results of the incubation study indicated that BGA levels in 5\% oil-contaminated+sludge-amended soil samples were significantly higher than those in oil-contaminated soil $(p<0.05)$. Wastewater sludge application enhanced BGA levels in soil contaminated with crude oil. At the end of the incubation period, the maximum BGA levels were observed in 5\% oil-contaminated+sludge-amended soil. Variations of dehydrogenase activity levels in crude oil-contaminated and crude oil-contaminated + sludge-amended soils during the 150-day incubation period are shown in Figure 6. 

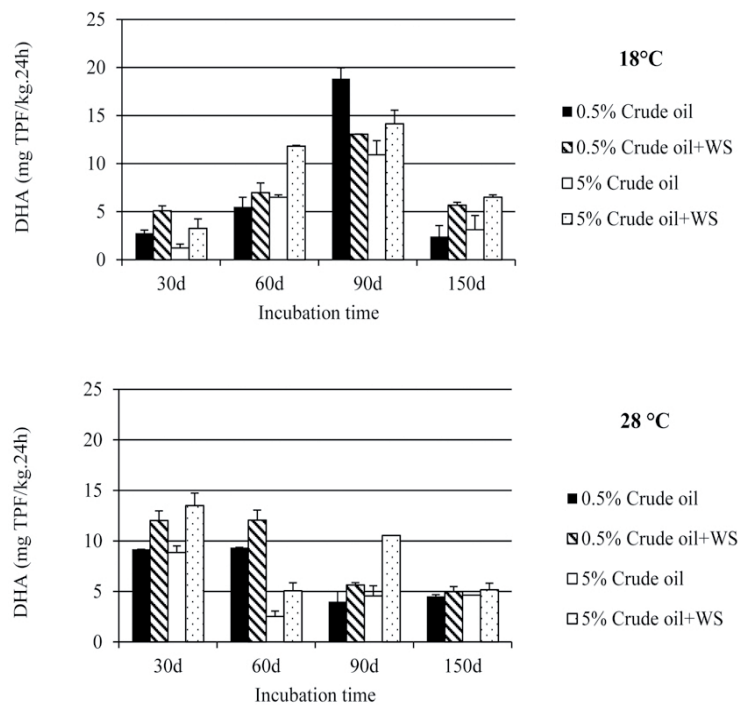

Figure 6. Changes in DHA in contaminated and sludgeamended soil during the incubation period (WS: wastewater sludge)

The results showed that wastewater sludge application stimulated DHA levels in crude oil-contaminated soil.

According to Figure 6, a high dose of crude oil (5\%) contamination further inhibited DHA compared with the application of a low dose of crude oil $(0.5 \%)$. The DHA levels in all treatments decreased with increasing incubation time at $28{ }^{\circ} \mathrm{C}$. The application of crude oil $(0.5 \%$ and $5 \%)$ resulted in an initial DHA concentration of $11 \mathrm{mg} \mathrm{kg}^{-1} \cdot \mathrm{h}$ in contaminated soils. The results showed that the DHA levels in crude oil-contaminated soils were apparently lower than those at the end of the incubation period.

At $18{ }^{\circ} \mathrm{C}$, DHA levels in all treatments increased as the incubation time increased during the first 90 days. Maximum DHA levels in all treatments were observed on the $90^{\text {th }}$ day. For other incubation periods, the DHA levels in the soil were apparently lower than the initial DHA level. In general, the DHA levels were higher in soils contaminated with a low dose of crude oil, indicating the inhibition effect of higher doses of crude oil on DHA.

\section{Discussion}

\subsection{Total Petroleum Hydrocarbons}

Biodegradation by natural populations of microorganisms represents one of the primary mechanisms by which petroleum and other hydrocarbon pollutants can be eliminated from the environment. In this study, natural biodegradation of hydrocarbons was significant in soils without wastewater sludge. Besides, the addition of organically rich wastewater sludge amendment facilitated the degradation of crude oil. The result showed that Hur and Park (2003) also stated that the amendment of wastewater sludge increased the degradation rate of the crude oil. Supplementation of the soil with organic matter, as a repository of an available pool of organic compounds, is key during the adaptation of the ecosystem to unfavourable environmental conditions. Our result showed that wastewater sludge application was not significant affect at $18{ }^{\circ} \mathrm{C}$ for TPH removal. Walworth et al., (2001) reported that hydrocarbon degradation is increased at higher temperatures. TPH levels in soil were found decreased when incubation time increased. Bastida et al., (2016) reported that the long-term respiration was lower in the contaminated samples in comparison to controls, probably as a consequence of extended exposure of microorganisms to pollutants.

\subsection{Soil enzyme activities}

Enzyme activities are commonly used as indicators of soil health because they play an important role in nutrient cycling, and can be sensitive indicators of pollution with hydrocarbons, heavy 
metals or pesticides (Wolińska et al., 2015). Thus, in the current study, we established soil biological activity by measuring UA, APA, BGA and DHA. The results obtained confirm that soil enzyme activity is determined by the degree of crude oil pollution.

Urease activity plays an important role in the mineralisation of nitrogen compounds. This enzyme forms stable complexes (urease-humus) and markedly contributes to soil fertility (Nannipieri et al., 2002). Soil urease activity is a good indicator, reflecting the mineralisation potential of organic nitrogen compounds in soil.

The results showed that wastewater sludge application stimulated UA levels in crude oil-contaminated soil. This result suggested that the high carbon content in oil was used as a substrate. Studies have reported that an increase in the number of hydrocarbon utilisers is positively correlated with hydrocarbon concentration. The increase in the numbers of culturable hydrocarbon-degrading bacteria demonstrates how rapidly indigenous soil microorganisms adapt to new substrates (Margesin et al., 2000).

The UA levels in soils with high levels of oil contamination $(5 \%)$ were higher than low levels of oil contamination both incubation temperatures. Crude oil may well provide as organic carbon sources, and an upgrading of oil degrading microbial populations (Margesin et al., 2000).Various factors may limit the rate of degradation including a deficiency of essential nutrients such as nitrogen. Many studies have previously demonstrated that the application of nitrogen to soil can improve microbial activity, measured using a variety of methods including enzyme assays and biomass (Lee et al., 2007). The impact of the nitrogen fertilizers on soil microflora could be explained by the temporary enrichment of the soil with a readily available $\mathrm{N}$ source. Our result indicated that crude oil contamination did not adversely affect UA levels. Soil urease activity exhibited a stronger re- sponse to petroleum treatment (Emami et al., 2014). Phosphatase is an enzyme of great agronomic value because it hydrolyses and transforms organic phosphorus compounds into different forms of inorganic phosphorus, which can subsequently be assimilated by plants. Phosphatase activity (PA) is important to soil $\mathrm{P}$ cycling. PA is sensitive to environmental perturbations and might therefore be a suitable selection for inclusion in the soil quality index (Turgay et al., 2010). This study clearly demonstrated the application of wastewater sludge in biodegradation of TPH by native microbial consortium not only as biostimulant, but also as inducers of degrader enzymes released by the microorganisms. Various authors (Amenaghawon et al., 2014) reported the positive effect of inorganic and organic fertilizers in the degradation of petroleum hydrocarbon in soil.

The present work results indicated that crude oil contamination did not affect adversely APA levels in soil. Turgay et al., (2010) reported that some enzymes, including phosphatase, are involved in $\mathrm{N}$ and $\mathrm{P}$ cycling and might not directly influence hydrocarbon presence. Enzyme induction during the degradation of crude oil depends on the crude oil composition and their metabolic products. Therefore, Kumari et al., (2016) supported the views that consortia with broad enzymatic capacities are more effective in the degradation of hydrocarbons in soil environment. $\beta$-Glucosidase activity (BGA) in soil might be particularly useful for soil quality monitoring because of the central role of this enzyme in soil organic matter cycling, which is generally regarded as an important component of soil quality (Turner et al., 2002)

In the present study, crude oil contamination did not affected negatively. The contamination with crude oil increased the amount of total organic and water-soluble C. Some compounds within these fractions may serve as energy sources for microbial populations (Bastida et al., 2016). However, the level of BGA in 
soils contaminated with crude oil was negatively affected after the addition of wastewater sludge. The amendment of wastewater sludge (reflecting the nitrogen content) can have deleterious effects (Walworth et al., 2007). Wastewater sludge mineralisation might inhibit the decomposition of less-biodegradable compounds.

Soil dehydrogenase enzymes are one of the main components of soil enzymatic activities participating in and assuring the correct sequence of all of the biochemical routes in soil biogeochemical cycles. Measuring the changes in soil enzyme activities might provide a useful index of the changes in soil quality. The soil dehydrogenase activity in soils provides correlative information on the biological activity and microbial populations in soil. Soil dehydrogenase activity exists in soils as an integral part of intact cells. As these enzymes do not reside in extracellular locations in the soil, dehydrogenases play a significant role in the biological oxidation of soil organic matter through the transfer of protons and electrons from substrates to accepters. Thus, the activity of dehydrogenases reflects the rate of transformations occurring in the soil (Kaczyńska et al., 2015).

The results obtained confirm that DHA is strongly determined by the degree of crude oil pollution.

DHA levels in the soil were more affected by high dose of crude oil contamination. Malachowska et al., (1997) also reported low levels of dehydrogenases in soils polluted with petroleum spillage. The concentration of petroleum hydrocarbon had a significant effect on soil dehydrogenase activity. The negative influence of polycyclic aromatic hydrocarbons on the activity of dehydrogenases was reported in Gianfreda et al., (2006). They proved this on the basis of studies on samples of soil exposed to contamination by crude oil for 50 years.
This report emphasises the particular susceptibility of dehydrogenases to the presence of petroleum products in the soil. Our studies lasted for only 150 days, but even during this period, significant changes in the influence of the individual crude oil on dehydrogenase activity could be observed. The results showed that wastewater sludge application stimulated DHA levels in crude oil-contaminated soil. This result might reflect differences in the nutrients in wastewater sludge, particularly $\mathrm{N}$ and $\mathrm{P}$, which stimulate indigenous microorganisms. The addition of $\mathrm{N}$ and $\mathrm{P}$ to oil-polluted soil accelerates the biodegradation of the petroleum in soil. In another research, it was proved that biosolid was useful in the biostimulation of soils contaminated with petroleum products (Kaczyńska et al., 2015).

\section{Conclusions}

The results of the present study indicated that enzyme activity levels in crude oil polluted soils varied with the level of contamination, time, temperature and the enzyme studied. The measured enzyme activities (UA, DHA, APA and BGA) were generally higher in soils contaminated with $0.5 \%$ crude oil, indicating the possible inhibition effect of heavy pollution with crude oil. On the other side, the removal of TPH in soil contaminated with crude oil was positively affected by the addition of wastewater sludge. High temperature contributed to the removal of TPH in soil contaminated with crude oil. Wastewater sludge application also showed a stimulating effect on crude oil-contaminated soil with respect to enzyme activities. The application of wastewater sludge to soils contaminated with crude oil generally increased APA, DHA, UA and BGA levels of soil. The increment in activity levels were more pronounced in case of heavy pollution. According to the obtained results, it may be 
concluded that measuring soil enzymatic activities can provide information concerning the function and structure of soil microbial communities in crude oilcontaminated soils.

\section{Acknowledgment}

This work was financially supported through a grant from the Commission of Scientific Research Projects of Uludag University (Project No. M-2011/28).

\section{References}

Alrumman, S.A., Standing, D.B., Paton, G.I. 2015. Effect of hydrocarbon contamination on soil microbial community and enzyme activity. Journal of King Saud University Science. 27, 31-41.

Amenaghawon, A.N., Osunbor, O., Obahiagbon, K.O. 2014. Impact of nutrients, aeration and agitation on the bioremediation of crude oil polluted water using mixed microbial culture. Int J Sci Res Environ Sci. 2(2), 43-48.

Anonymous, 1985. Standard Methods hospha Examination of Water and Wastewater. APHA-AWWAWPCF, Copyright by American Public Health Association, Washington, p. 1269.

Bandick, A.K., Dick, R.P. 1999. Field management effects on soil enzyme activities. Soil Biol. Biochem. 31,1471-1479.

Bastida, F., Jehmlich, N., Lima, K., Morris B.E.L., Richnow, H.H., Hernández, T., von Bergen, M., García, C. 2016. The ecological and physiological responses of the microbial community from a semiarid soil to hydrocarbon contamination and its bioremediation using compost amendment. Journal of Proteomics. 135, 162-169.
Bremner, J.M., Mulvaney, C.S. 1982. Nitrogen-total In: Page, A.L., Miller, R.H. (Eds.), Methods of Soil Analysis. Part 2, Agron. Monogr, second ed., vol. 9. ASA and SSSA, Madison, WI, pp. 595-624.

Emami, S., Pourbabaei, A.A., Alikhani, H.A. 2014. Interactive effect of nitrogen fertilizer and hydrocarbon pollution on soil biological indicators. Environmental Earth Sciences. 72, 9, 3513-3519.

Gianfreda, L., Mora, M.L., Diez, M.C. 2006. Restoration of polluted soils by means of microbial and enzymatic processes. J. Soil Sci. Plant Nut. 6, 20-40.

Gianfreda, L. 2015. Enzymes of importance to rhizosphere processes, Journal of Soil Science and Plant Nutrition. 15 (2), 283-306.

Hur, J.M., Park, J.A. 2003. Effects of sewage sludge mix ratio on the biodegradation of diesel-oil in a contaminated soil composting. Korean J. Chem. Eng. 20, 307-314.

Isaac, R.A., Johnson Jr, W.C. 1998. Elemental determination by inductively coupled plasma atomic emission spectrometry. In: Kalra, Y.P. (Ed.), Handbook of Reference Methods for Plant Analysis. CRC Press, Boca Raton, Florida, USA., pp. 165-170.

Kaczyńska, G., Borowik, A., Wyszkowska, J. 2015. Soil Dehydrogenases as an Indicator of Contamination of the Environment with Petroleum Products. Water Air Soil Pollut. 226, 372.

Keeney, D.R., Nelson, D.W. 1982. Nitrogen e inorganic forms. In: Page, A.L. (Ed.), Methods of Soil Analysis, Part 2, Agron. Monogr, second ed., vol. 9. ASA and SSSA, Madison, WI, pp. 643-698.

Kumari, B., Singh, S.N., Singh, D.P. 2016. Induced degradation of crude oil mediated by microbial augmentation and bulking agents. Int. J. Environ. Sci. Technol. 13, 1029-1042. 
Lee, S.H., Lee, S., Kim, D.Y., Kim, J.G. 2007. Degradation characteristics of waste lubricants under different nutrient conditions. J Hazard Mater. 143, 65-72.

Makoi, J.H.R., Ndakidemi, P.A. 2008. Selected soil enzymes: examples of their potential roles in the ecosystem. Afr J Biotechnol. 7, 181-191.

Malachowska, J.A., Mirozoska, J., Rozielska, M., Miksch, K. 1997. Enzymatic activity in soil contaminated by petroleum derivatives during the process of its detoxication. J Biotechnol. 36, 79-91.

Margesin, R., Zimmerbauer, A., Schinner, F. 2000. Monitoring of bioremediation by soil biological activities. Chemosphere. 40, 339-346.

Marinescu, M., Toti, M., Tanas, V., Plopeanu, G., Calciu, I., Marinescu, M. 2011. The effects of crude oil pollution on physical and chemical characteristics of soil. Research Journal of Agricultural Science. 43(3), 125-129.

Martinez-Salgado, M.M., Gutiérrez-Romero, V., Jannsens, M., Ortega-Blu, R. 2010 Biological soil quality indicators: A review. In: Current Research, Technology and Microbiology and Microbial Biotechnology, MendezVilas A (Editor.), Formatex. www.formatex.info/microbiology2/319- 328.pdf.

Nelson, D.W., Sommer, L.E. 1982. Total carbon, organic carbon, and organic matter. In: Page, A.L. (Ed.), Methods of Soil Analysis, ASA Monogr, second ed., vol. 9(2). American Society of Agronomy, Madison, WI, pp. 539-579.
Palese, A.M., Giovannini, G.L., Dumonte, S., Perucei, P. 2003. Effect of fire on soil C, N and microbial Biomass. Agronomite. 24, 47-53.

Tabatabai, M.A. 1994. Soil enzymes. In: Weaver, R.W., Angle, S., Bottomley, P. (Eds.), Methods of Soil Analysis. Part 2: Microbiological and Biochemical Properties. Soil Science Society of America, Madison, pp. 775-833.

Turgay, O.C., Erdogan, E.E., Karaca, A. 2010. Effect of humic deposit (leonardite) on degradation of semi-volatile and heavy hydrocarbon and soil quality in crude-oil contaminated soil. Environ. Monit. Assess. 170, 45-58.

Turner, B.L., Hopkins, D.W., Haygarth, P.M., Ostle, N. 2002. [beta]-Glucosidase activity in pasture soils. Appl. Soil Ecol. 20, 157-162.

Walworth, J., Braddock, J., Woolard, C. 2001. Nutrient and temperature interactions in bioremediation of cryic soils. Cold Reg. Sci. Technol. 32, 85-91.

Walworth, J., Pond, A., Snape, I., Rayner, J., Ferguson, S., Harvey, P. 2007. Nitrogen requirements for maximizing petroleum bioremediation in a sub-Antarctic soil. Cold Reg. Sci. Technol. 48, 84-91.

Wolińska, A., Kuźniar, A., Szafranek-Nakonieczna, A., Jastrzebska, N., Roguska, E., Stępniewska, Z. 2016. Biological Activity of Autochthonic Bacterial Community in Oil-Contaminated Soil. Water Air Soil Pollut. 227, 130. 